\title{
The implementation of community based tourism model in the development of the Semambu Island tourism village, Ogan Ilir Regency, South Sumatra
}

\author{
Ulfa Sevia Azni ${ }^{1 *}$, Alfitri ${ }^{2}$ \\ ${ }^{1}$ Masters in Environmental Management, Postgraduate Studies, Universitas Sriwijaya, Indonesia \\ ${ }^{2}$ Department of Sociology, Faculty of Social and Political Sciences, Universitas Sriwijaya, Indonesia \\ "Corresponding author \\ E-mail address: ulseaz97@gmail.com \\ DOI: https://doi.org/10.21107/sml.v3i1.6915
}

\begin{tabular}{|c|c|}
\hline Article Info & Abstract \\
\hline $\begin{array}{l}\text { Keywords: } \\
\text { Community based } \\
\text { tourism } \\
\text { CBT model } \\
\text { Community } \\
\text { empowerment } \\
\text { Tourism village } \\
\text { Semambu Island } \\
\text { tourism village }\end{array}$ & $\begin{array}{l}\text { This article examines the implementation of CBT model in the development } \\
\text { of the Semambu Island Tourism Village. This research uses qualitative } \\
\text { research with descriptive research type. Sampling is done by purposive } \\
\text { sampling technique, and collecting data is done by in-depth interviews. This } \\
\text { study aims to describe the application of CBT (Community Based Tourism) } \\
\text { in the management of Semambu Island Tourism Village, the role of various } \\
\text { stakeholders, and development in the management and development of } \\
\text { Semambu Island Tourism Village in North Indralaya District, Ogan Ilir } \\
\text { Regency, South Sumatra. The results showed the concept of CBT applied } \\
\text { to achieve tourism planning in this place was applied in the form of local } \\
\text { community participation, the establishment of a tourism protection village, } \\
\text { management of tourist attraction with an environmental perspective and } \\
\text { the creation of community business activities. Management of tourist } \\
\text { attractions in the Semambu Island Village emerged from the discovery of } \\
\text { local communities. With several considerations concerning the development } \\
\text { of Semambu Island Tourism Village, it still needs funding assistance from } \\
\text { the local government, providing facilities and infrastructure as a tourist } \\
\text { attraction, increasing the number of tourists, and the still limited ideas to } \\
\text { add complementary businesses and Semambu Island Tourism Village. }\end{array}$ \\
\hline
\end{tabular}

Citation suggestion:

Azni, U. S., \& Alfitri. (2020). The implementation of community based tourism model in the development of the Semambu Island tourism village, Ogan Ilir Regency, South Sumatra. Simulacra, 3(1), 109-120. https://doi. org/10.21107/sml.v3i1.6915

Received 21 March 2020; Received in revised form 30 April 2020; Accepted 8 May 2020; Published online 25 June 2020. 


\section{Introduction}

All Indonesians hope for the increase and spreading of community-based development and economy in the villages. Currently, villages are no longer mere spectators of development. Indeed, they have become actors in activities development. Villages have substantial potentials that could be managed and developed by village administration and with the community. One of the developable potentials is the tourism village. The Indonesian Government have initiated the development of tourism potential at the village level, the sole requirement being the village's potential is marketable and promote the local economy (Susyanti, 2013).

Tourism village is a rural area that reflects an overall atmosphere and authenticity of rural areas, including socio-culture, customs, daily life, as well as unique architectural building and village spatial structure (Priasukmana, 2013). The area usually has a population that is still relatively original in terms of traditions and culture. It also has maintained other supporting factors, such as food, agricultural and social systems, and environmental factors (Zakaria, 2014).

Tourism village develops an area in the village without changing elements that already exist. Instead, it tends to develop the potential of the village by turning existing elements as attributes of tourism products on a small scale into a series of activities or tourism activities. Supposedly, it can provide and fulfill tourist needs, both from the attraction and a supporting facility.

One of the exciting factors in a tourist village is its local attraction based on the original culture. Indeed, the cultural uniqueness of the local communities underlies the creation of tourism activities in a village. Other requirements include 1) good accessibility, tourists can visit using various types of transportation; (2) having fascinating tradition, such as nature, arts and culture, legends, local food that can be developed as tourist attractions; (3) Sufficient support from the community and village administration for the tourism and tourists or visitors; (4) Security; (5) Adequate accommodation, telecommunications and crews; (6) cool and cold climates; (7) related to other well-established tourism (Hadiwijoyo, 2012).

As one of the stakeholders, the village communities have an essential role in supporting the success of tourism development [6]. Their role includes planning the implementation of the tourism development activities framework. Therefore, to support the success of tourism development, every development effort or program implemented must pay attention to the position, potential, and role of the community as the subject or agent of development (Sunaryo, 2013). In addition, the implementation must follow the conventional rules in accordance with the beliefs of the local community (Komariah, 2018).

Community-Based Tourism (CBT) concepts describe the role of the community in tourism development (Nugroho, 2018). CBT is an approach to tourism development that emphasizes the local community, directly and indirectly, involved in the tourism industry (Purnamasari, 2011). According to Weaver, CBT is a form of alternative tourism (Weaver, 2010). This concept is expected to be an alternative to mass tourism, most of which cause a decline and even damage the natural, cultural, and social environment.

CBT operations are composed by several principles including recognizing, supporting and promoting community ownership of tourism attraction, involving community members in all development aspects, promote community pride, improving the quality of life, guarantying environmental sustainability, maintaining the unique character and culture of the local area, promoting cross-cultural learning, 
respecting cultural differences and human dignity; distributing benefits equally among community members; contributing income to community activities.

CBT is the basis of sustainable tourism development in which the community is no longer the object of development but instead as the determinant of development itself (Koentjoro, 2006). Similarly, Hudson and Timothy thought that community-based tourism or CBT is community engagement with the certainty of benefits for the community. It is done through planning and assistance efforts that favors local communities and other groups who have enthusiasm or interest in tourism by tourism management that provides more significant opportunities to achieve the welfare of the local community (Sunaryo, 2013).

One of the villages whose communities are highly enthusiastic about developing their village's tourism sector was Pulau Semambu Village. The enthusiasm was initially stemmed from local village youth. They wanted to develop a village's tourism sector, which is also balanced with the village's natural potential. Therefore, the researchers aimed to study the development of Pulau Semambu Tourism Village, which was based on the CBT concept. The researchers hopes that the village can inspire good cooperation between communities and the emergence of local-based businesses managed by the local community.

\section{Method}

This research was descriptive research using a qualitative approach. This type of research seeks to describe and explain the object of the study in detail (Moleong, 2006). The sample was selected using purposive sampling technique, while the data collection technique was done by collecting primary data, namely in-depth interviews and observation. Secondary data was literature studies and various relevant research results. The subjects of this research were the people of Pulau Semambu Village, analyzed using the Miles and Huberman model composed of several stages. The stages were data codification stage, data presentation stage and verification or conclusion stage.

The purpose of this study was to describe the application of CBT in the management of Pulau Semambu Tourism Village. This research also aimed to describe the role of various stakeholders in the management and development of Pulau Semambu Tourism Village, North Indralaya District, Ogan Ilir Regency, South Sumatra.

\section{Results and Discussion}

\section{Application of CBT in the Management of Pulau Semambu Tourism Village}

Profile of Pulau Semambu tourism village

Pulau Semambu Village was located in Hamlet III Pulau Semambu Village, North Indralaya District, Ogan Ilir Regency, South Sumatra. It was not difficult to access the road to this village. From downtown Palembang City, it would take \pm 50 minutes to reach Indralaya. The village was located to the right of the junction right next to the Indralaya gas station.

Upon arrival, visitors could enjoy an impressive view, despite it being in the development process. However, the natural nuances could make visitors feel at home and comfortable. Electricity and telecommunications were available and could support the activities of Pulau Semambu Village. Nevertheless, the facilities, infrastructure, and human resources could still be improved. Based on an interview with Supramin, Pulau Semambu Village head, researchers found that the village covered an area of around 1200 hectares composed of 5 hamlets and 10 Neighborhood associations (RT). 
This natural tourism village was the product of the local village youths' creativity. The youths were inspired by their experience of travelling to other areas such as Bandung and Bogor. They realized that their village has good natural resource potential. Then, they formed an initiative to establish Pulau Semambu Village as an attractive tourist destination. Pulau Semambu Tourism Village was managed by several local village youths coordinated by Kodrat (29).

Furthermore, the village was also overseen by the Village Head and the local Village-owned Enterprises. The village offered various attractions. Some of the attractions include flying fox, outbound activities, livestock and fish feeding, fruits and vegetable picking, fishing grounds. It also offered prayer rooms and parking lots. According to Supramin, the tourism village was established in November 2017. It was built on a one-hectare land owned by $\mathrm{H}$. Nasrul Shah, a resident of Pulau Semambu Village. Supramin stated that Nasrul Shah voluntarily devoted his land to the village development managed by the village youths. When it was first built, Kodrat and his team, acknowledged by the village head, initially proposed to use the land as a Pulau Semambu Tourism Village. Then, Kodrat, along with other youths and the local community, began to clear the land and turn it into a natural tourism attraction. It was immediately officiated by the village head.

During the interview, Kodrat explained that Pulau Semambu Tourism Village offers entertainment packages composed by games, flying fox, outbound, lunch, coffee break, vegetables and fruit picking, fishing, animals feeding or according to program package requests from visitors. The program package offered by Pulau Semambu Tourism Village includes outbound programs priced at 250,000 IDR per person. This package includes outbound, lunches, coffee breaks, vegetable picking tours, fruit picking tours, fishing and documentation.
As program manager, Kodrat also confirmed that the village could provide facilities that cater to the needs of visitors. For example, if visitors wanted to make a gathering event, the crews would prepare a stage, music, and tents and chairs. If visitors wanted to camp, the crews would prepare electricity and other facilities to cater to the visitors' needs. However, Pulau Semambu Tourism Village did not have entrance tickets because the crews thought that their attractions were still somewhat limited.

To introduce Pulau Semambu Tourism Village, the management and community initially introduced the village by visiting various elementary, middle, and high schools because the target visitor was children. However, over time, Pulau Semambu Tourism Village has become increasingly well-known and visited by a wide range of tourists group. Based on the interview, the visitors have reached 1500 from its opening in February 2018 until November 2019. This result was inseparable from the role of social media such as Instagram and Facebook. Pulau Semambu Tourism Village has an Instagram and Facebook social media account managed by one of the community members, which was used to promote the attraction.

\section{Local community participation}

The term participation comes from the Latin word 'participate' which means 'to take part' or 'to participate.' Participation is defined as an interaction between two groups. One group is not included in the decisionmaking process (nonelite), and the other is involved (elite) (Najih, 2006). Meanwhile, according to Sumarto, participation refers to a process when citizens (as individuals, social groups and organizations) take part in and influence the planning, implementation, and monitoring of policies that directly impact community life (Sumarto, 2009). 
Meanwhile, community participation is the direct and indirect participation, involvement, and equality of community members in a particular activity. It starts with the idea, policy formulation, program implementation, and evaluation (Rubiantoro, 2013). In developing a tourism village, community participation is one of the keys to ensure the development of a tourism village runs in accordance with the expectation. Community participation cannot be ignored because the local community has a deeper understanding of the area compared to outsiders.

Thus, the participation of local communities is vital in the planning, implementation, development, and evaluation process to promote awareness and responsibility to participate in the development of tourist attractions. In the development of tourism village, the community plays as both subject and object at the very heart of the development sustainability. Indeed, the development of tourism is very close to the lives of village communities.

Based on the field observations, the researchers revealed that the participation implemented in the initial process of the establishment of Pulau Semambu Tourism Village was spontaneous. The main characteristic of spontaneous participation is that the initiative comes from the community (bottom-up). This character was evident in the initial stages in which a group of young people in the village community recognized and took the initiative to develop the village's tourism sector. Spontaneous participation is also marked by community involvement as decision-maker. This characteristic was exhibited during the formation of institutions and management of the tourist attractions in which all components of the village community were in their respective capacity-based roles.
Images above depicted the community and young people in Pulau Semambu Tourism Village, clearing the land designated for the tourism village. They worked together in the initial process of development. In addition, community participation was also evident in flying fox track building, tourism promotions, and social media management.

Aside from conducting joint meetings and mutual cooperation to achieve the desired tourism object in their villages, community participation was also apparent in the planning and establishment of tourism awareness group or pokdarwis consisting of local youths supervised directly by the local village administration. In addition, local communities participated in the development of the village is tourism by being aware of the need to maintain the tourist attraction and being involved in the decisions making process. The community also participated in the promotion of the tourism village through their respective social media, official websites, and brochures.

\section{Tourism village institution}

In the context of tourism, institutions are an essential component in the success of tourism. Institutions also play a role in managing resources and distributing benefits to increase tourism potential. In addition, the urgency of institutions in the tourism field acts as a mobiliser in facilitating and developing community participation (Triambodo, 2015).

The Pulau Semambu Tourism Village Institution carried out its duties based on leadership functions, internal partnerships, tourist attractions development, and human resources building. Based on CBT (Community Based Tourism), institutionally, the development and management of Pulau Semambu Tourism Village were carried out as follows: 


\section{Pulau Semambu Village administration}

In general, the Pulau Semambu Village administration was in charge of establishing relationships with the Government, private party, and local communities and attract them to participate in building the village security, funding, and promotional activities.

\section{Tourism Awareness Group (Pokdarwis)}

Pokdarwis consists of young people and community members who had the idea and initiated the development of Pulau Semambu Tourism Village. Pokdarwis or commonly called the 'crew' was composed of 15 people. In general, pokdarwis, as the manager of tourist attraction, must coordinate with the village administration and the local community, especially in the policy, management, and overall synergy.

\section{Market or visitors}

Visitors of Pulau Semambu Tourism Village were individuals, groups or institutions. Therefore, it was necessary to study the market potential in the context of targeted promotion and recreational service needs.

\section{Government, higher education, and private party}

The Government played a role in making policies. The policies should be transparent and fair. Public policies must meet the standards of democracy. Furthermore, direction and funding are still necessary to develop tourism potentials. Higher education could assist and facilitate skill development. It can also be a way to apply Tri Darma Perguruan Tinggi (Three main deeds of higher education). The private sector is essential in funding. Local community and Government could not be expected to provide a massive budget. Therefore, synergy with the private sector could be the win-win strategy.

However, in general, Pulau Semambu Tourism Village institutional structure consisted of an advisory board and a board of directors which is composed by the Pulau Semambu Village administration. In addition, there were community members responsible for the activities, a secretary, a treasurer, and persons in charge of program activities.

\section{Activities and Benefits for the Community}

The community directly gained the following benefits: 1 ) farmers could sell their goods above the market price because their crops were for used for vegetables picking and fruit harvesting activities; 2) traders can open stalls and benefit from the visitors' businesses; 3) Local businesses often catered for the visitors' meal and snacks.
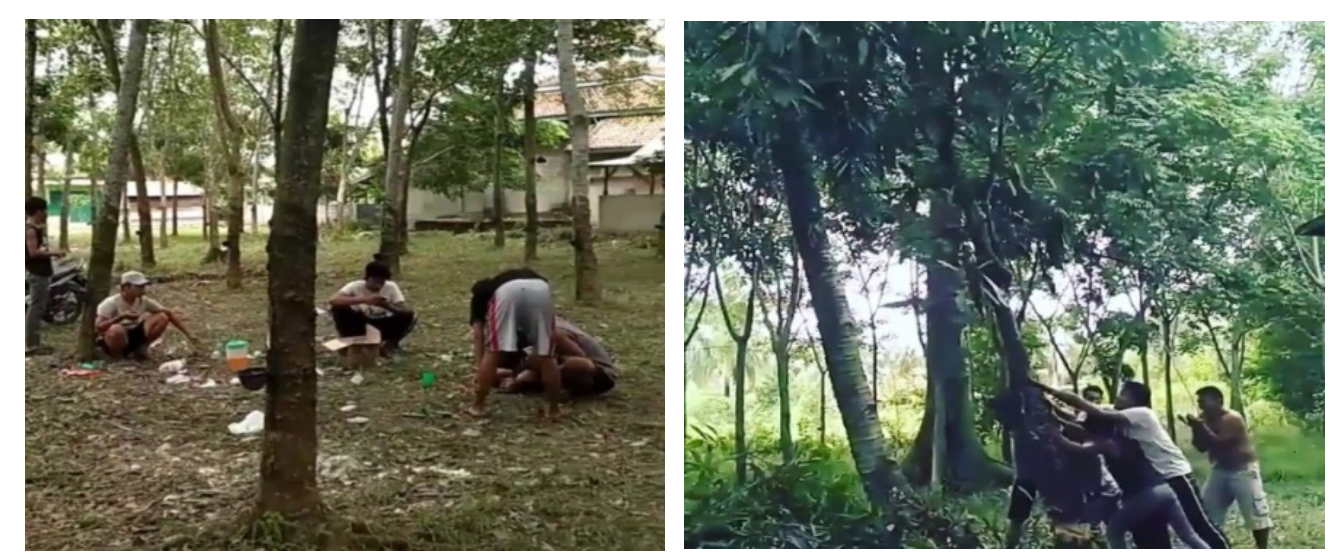

Image 1. The community cooperation in Pulau Semambu Tourism Village 
However, from the overall benefits gained from the activities and community business, the managers only focused on program activities in Pulau Semambu Tourism Village. Whereas the village has the potential of innovative tourism business, ranging from souvenirs, homestays and local culinary businesses, such as vegetable and fruit chips, even if development priorities were directed at managing tourist attractions, other business products should have been emphasized as well. Indeed, all tourism products are closely related. With the increasing number of business products, tourists would have various choices to enjoy the tourism village. In addition, with the increasing number of emerging products, the community could gain economic benefits from tourism activities in their villages.

\section{Environmental Management}

Success in tourism development was initially measured by the number of income. However, such a concept is no longer relevant today due to environmental interests. Conceptually, sustainable tourism is based on community, social and economic empowerment to promote the growth of socio-cultural, economic quality, and guaranteeing sustainability in the environment (Putra, 2000). In addition, environment-friendly tourism village model usually does not pose any danger because it does not change the culture and local customs. Instead, it encourages the existing potential to have a value to attract tourists and supply it with supporting facilities and infrastructure to improve villagers' welfare.

Based on the researcher's observation, the management of the tourist attraction of Pulau Semambu Village has started to consider the environment. This is evident in the fact that the managers paid attention to the carrying capacity of the environment and ensured that the development utilized environmentally friendly facilities, such as colorful decorations from used bottles and tires. However, it should be warranted that management maintains its consistency in managing the environment. Such a stance was tested as more and more tourists came into the village. Therefore, innovation and creativity must continue to be explored so

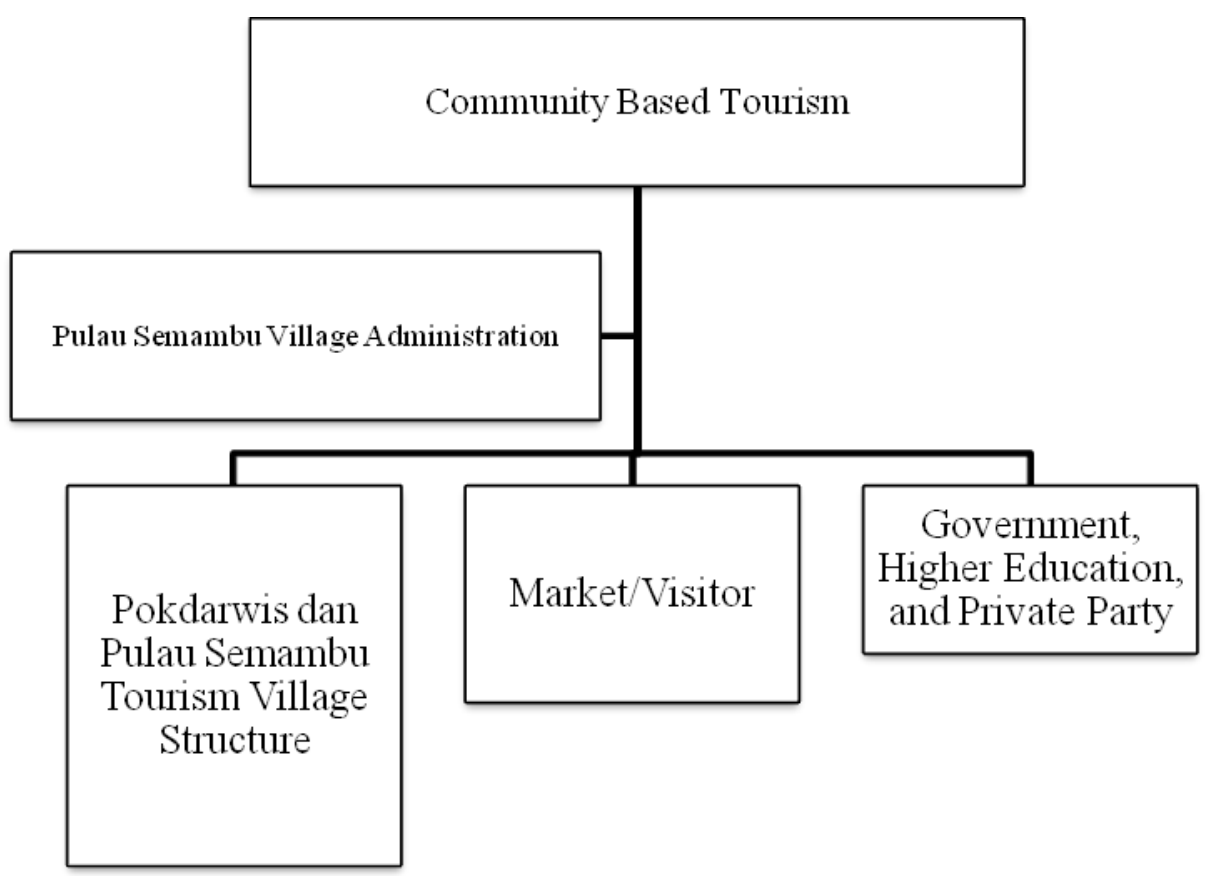

Figure 2. Institutions in the Management of Pulau Semambu Tourism Village 
that visitors can continuously enjoy the variety of attractions offered by the village.

Therefore, it can be concluded that the application of CBT in the management of Pulau Semambu Tourism Village was based on the participation of local communities, the tourism village institutions, the communities' creation of activities and businesses, as well as environmentally sound management.

\section{The Role of Stakeholders in the Management and Development of Pulau Semambu Tourism Village}

In tourism development activities and development in other sectors mainly involves the role of all existing and related stakeholders. The stakeholders are composed of three parties: Government, Private Party, and Community with their respective roles and functions (Ministry of Tourism and Creative Economy, 2012).

The institution is expected to actively participate in planning, implementing and controlling because tourism development is a very complex effort. Thus, the involvement of all related stakeholders is critical. Indeed, the synergy between formal and informal institutions make more organized and can minimize the negative impacts of tourism. A good institution in the management system must also be supported by proper socialization and control to ensure the institution to run effectively (Aulia, 2010).

\section{The role of communities as actors}

According to the Marine National Sanctuaries, traditional and cultural communities play a significant role in preserving biodiversity related to participation, land and resources use, as well as democracy in the context of tourism development. Communities must also participate in planning stages, including assessing resources, identifying problems, and action definition (Tanzania Coastal Tourism Situation Analysis, 2001).

Wearing explained that the success or long-term success of the tourism industry is highly dependent on the level of acceptance and support from the local community (Wearing, 2001). This issue is closely related to the community, which is a group of people who have been living and interacting together for a long time. These interactions create values, norms, and culture (Burhan, 2007). Therefore, with the participation of local people who have a deeper understanding of the area can ensure tourism may run smoothly. Indeed, the community will feel more included in each of the activities.

Pulau Semambu Village community, especially the young people, had a significant role in initiating tourism villages and managing tourist attractions. At the planning, implementation and evaluation stages, the community was always involved based on their respective duties and portions. The role of the community in managing tourist attraction experienced slow growth. This is evident in the initial planning process from 2017 to the current evaluation phase. They were still focused on one tourist attraction. This is due to the development using a community approach as a subject that must accommodate ideas and policies from many parties. Thus, the decision-making process took a long time.

Therefore, it was hoped that the community and managers to form a more efficient and targeted decision-making system. Therefore, the tourist attraction management can run faster and increase economic benefits from tourism activities which can be evenly distributed to the people of Pulau Semambu Tourism Village.

\section{The Government's role as a facilitator}

The Government as a facilitator in the tourism development usually acts as 
assistance through training, education, and skills upgrading, as well as in the funding or capital through the provision of capital assistance to empowered communities (Nurdin, 2014). From this understanding, the Government is expected to become a facilitator for Pokdarwis, both in terms of providing training, funds, and capital.

Nevertheless, based on the researcher's observations, the Government has not been fully involved in the development in this village. The Government should have provided more support to nurture the spirit of the community to manage tourist attractions. Therefore, sustainable management is possible. The Government, in this case, was the local village administration and the Government of Ogan Ilir Regency.

\section{The private party as a developer/investor}

In the case of developing tourist villages, the private party is the outsider that views tourists as an opportunity to gain profits by providing products and services to support or accommodate travel activities and to ensure tourist satisfaction. Usually, the private sector has previously cooperated with the management.

In addition, the private sector is expected to respond to the needs of the community quickly and efficiently and to be more involved in operational activities, especially in the production and distribution of public services. For certain public services that are local, unique and specific, the community will be able to play a more active role compared to the Government and private sector (Dwiyanto, 1996). The more portion the private sector take in the delivery of public services, the more opportunity is given for the Government to focus on the more strategic functions as a regulator, facilitator and promoter of public services.

However, the study indicated that the role of the private sector in managing tourist attractions in the village is minimal. This may be caused by the Pokdarwis' role and the high awareness of the local community. It did not provide many opportunities for investors. On the one hand, this showed the strength and influence of communities groups in the management of existing tourist attractions. On the other hand, the development of existing management was limited because it relied on the ideas of the community and the crew, which involved many members in decision making. However, according to the manager, those involved in the management of the tourism village were open to the private sector as long as it still benefits the community.

\section{Management and Development Strategy for Pulau Semambu Tourism Village}

According to KBBI, a strategy can be interpreted as a plan or strategy to achieve a specific purpose. In addition, a strategy is also interpreted as efforts or adjustments to react to certain environmental situations, where actions are consciously based on reasonable considerations (Badudu, 1994).

However, the implementation of the strategy would encounter the potential and obstacles encountered. Potential is something that is used as a material or source to be managed either through an effort by humans, or mechanical power. Potential can also be interpreted as an available resource (Kartasapoetra, 1987). Meanwhile, an obstacle is anything that can hinder progress or achievement.

Based on the researcher's analysis of the situation in Pulau Semambu Tourism Village, several potentials, advantages and, problems faced by the managers are revealed in the following section:

\section{Potential and superiority of Pulau Semambu} Tourism Village

1. A strategic place for tourism and refreshing activities; 
2. Relatively natural and beautiful condition;

3. Relatively large market or visitor potential;

4. Potential for tourism development with agro-tourism packages;

5. Support from the surrounding community;

6. Managers, the community and visitors were involved in the promotion process

\section{Problems and Constraints in Pulau Semambu Tourism Village}

1. Lack of facilities and infrastructure as a tourist attraction and support;

2. Lack of promotions and outbound variations;

3. Lack of proper tourism management due to the limited number and qualifications of the crew;

4. A limited idea related to the supporting business in Pulau Semambu Tourism Village.

Based on the potentials, strengths and weaknesses of Pulau Semambu Tourism Village, the researchers offered solutions to overcome the problems. Tourism development can use development strategies based on the CBT approach:

1. Strengthening the institutions managing Pulau Semambu Tourism Village;

2. Improving coordination between Villageowned Enterprises, the Government, and community groups;

3. Market penetration and expansion via tourism promotion;

4. Improving facilities and infrastructure;

5. Increasing human resource capacity in village communities;

6. Increasing the variety of complementary and supporting tourism services.

\section{Conclusion}

CBT (Community Based Tourism) concept was applied to achieve tourism management and development in Pulau Semambu Village. It was done in the form of local community participation, tourism village institution formation, environmentalfriendly tourist attraction management, and the creation of community business activities. Tourist attractions management in this village should have involved all tourism stakeholders, such as the Government and the private sector, to create sustainable management and development of tourism attractions in Pulau Semambu Village.

Pulau Semambu Tourism Village also has good potential to be further developed, including the relatively natural and beautiful condition, the potential for tourism development with an agro-tourism package program, as well as tremendous support from the youths and the surrounding community. However, management of the tourism village still faced several obstacles, such as lack of financial assistance from the local Government and limited tourist attraction facilities and infrastructure. In addition, the lack of tourism management was caused by the limited number of crews and ideas for supporting tourism businesses.

The researchers suggested that the concepts planning and management should be made in writing and agreed upon so that the targets achieved are clear; in addition, the crew meeting must be scheduled to establish good coordination. Furthermore, the local Government should assist in the form of funds and outreach via routine assistance for the Pulau Semambu Tourism Village to oversee the management and development of activities and ensure that the targets are met. 


\section{Acknowledgement}

The researchers would like to thank all those who have supported and helped carry out this research. In particular, we would like to thank the Head of Pulau Semambu Village, the tourism manager of Pulau Semambu Tourism Village, and the entire community of Pulau Semambu Village, Ogan Ilir, South Sumatra.

\section{Declaration of Ownership}

This article is our original work.

\section{Conflict of Interest}

There is no conflict of interest to declare in this article.

\section{Ethical Clearance}

This study was approved by the institution.

\section{References}

Badudu, J. S. (1994). Kamus umum bahasa Indonesia. Pustaka Sinar Harapan.

Burhan, B. (2007). Sosiologi komunikasi (teori, paradigma, dan diskursus teknologi komunikasi di masyarakat). Kencana Prenada Media Group.

Hadiwijoyo, S. S. (2012). Perencanaan pariwisata perdesaan berbasis masyarakat (sebuah pendekatan konsep). Graha Ilmu.

Kartasapoetra. (1987). Pengantar ekonomi produksi pertanian. Bina Aksara.

Kementerian Pariwisata dan Ekonomi Kreatif. (2012). Pedoman pokdarwis. Kementrian Pariwisata dan Ekonomi Kreatif.

Komariah, N. Saepudin, E., \& Yusup, P. M. (2018). Pengembangan desa wisata berbasis kearifan lokal. Jurnal Pariwisata Pesona, 3(2), 158-174.
Moleong, L. J. (2006). Metode penelitian kualitatif. Remaja Roskadarya.

Muljadi, A. J. (2012). Kepariwisataan dan perjalanan. Raja Grafindo Persada.

Najih, A. S., Wiryani, F,. \& Sirajuddin. (2006). Hak rakyat mengontrol negara: Membangun model partisipasi masyarakat dalam penyelenggaraan otonomi daerah. YAPPIKA.

Nugroho, D. S. (2018). Community based tourism tantangan Dusun Nglepen dalam pengembangan desa wisata. Jurnal Pariwisata, 5(1), 42-55. https://doi. org/10.31311/par.v5i1.3217

Nurdin, M., Nurmaeta, S., \& Tahir, M. (2014). Peran pemerintah daerah dalam pemberdayaan masyarakat petani jagung di Kecamatan Biringbulu, Kabupaten Gowa. Otoritas: Jurnal Ilmu Pemerintah, 4(1), 66-78. https://doi.org/10.26618/ojip. v4i1.81

Priasukmana, S., \& Mulyadin, R. M. (2013). Pembangunan desa wisata: pelaksanaan undang-undang otonomi daerah. Jurnal Info Sosial Ekonomi, 2(1), 37-44.

Purnamasari, A. M. (2011). Pengembangan masyarakat untuk pariwisata di kampung wisata Toddabojo, Sulawesi Selatan. Jurnal of Regional and City Planning, 22(1), 49-64. http://dx.doi. org/10.5614.2011.22.1.4

Rubiantoro, E. A., \& Haryanto, R. (2013). Bentuk keterlibatan masyarakat dalam upaya penghijauan pada kawasan hunian padat di Kelurahan Serengan, Kota Surakarta. Jurnal Pembangunan Wilayah dan Kota, 9(4), 416-428. https:// doi.org/10.14710/pwk.v9i4.6679

Sumarto, H. S. (2009). Inovasi, partisipasi, dan good governance: 20 prakarsa inovatif dan partisipatif di Indonesia. Yayasan Obor Indonesia.

Sunaryo, B. (2013). Kebijakan pembangunan destinasi pariwisata konsep dan aplikasinya di Indonesia. Gava Media. 
Susyanti, D. W. (2013). Potensi desa melalui pariwisata pedesaan. Jurnal Ekonomi dan Bisnis, 12(1), 33-36. https://doi. org/10.32722/eb.v12i1.650

Natl. Mar. Sanctuaries. (2001). Understanding tourism stakeholder (stakeholder paricipation). Tanzania Coastal Tourism Situation Analysis.
Wearing, S. (2001). Volunteer tourism: Experiences that make a difference. CABI.

Zakaria, F., \& Suprihardjo, D. (2014). Konsep pengembangan kawasan desa wisata di Desa Bandungan, Kecamatan Pakong, Kabupaten Pamekasan. Jurnal Teknik Pomits, 3(2), 245-249. https://doi. org/10.12962/j23373539.v3i2.7292 
